\title{
The social consequences of minor innovations in construction
}

Article

Accepted Version

Ewart, I. J. (2019) The social consequences of minor innovations in construction. Construction Management and Economics, 37 (9). pp. 537-549. ISSN 1466-433X doi: https://doi.org/10.1080/01446193.2019.1614202 Available at https://centaur.reading.ac.uk/79743/

It is advisable to refer to the publisher's version if you intend to cite from the work. See Guidance on citing.

To link to this article DOI: http://dx.doi.org/10.1080/01446193.2019.1614202

Publisher: Taylor \& Francis

All outputs in CentAUR are protected by Intellectual Property Rights law, including copyright law. Copyright and IPR is retained by the creators or other copyright holders. Terms and conditions for use of this material are defined in the End User Agreement.

\section{www.reading.ac.uk/centaur}

\section{CentAUR}

Central Archive at the University of Reading

Reading's research outputs online 
The social consequences of minor innovations in construction.

Ian J. Ewart ${ }^{\text {a* }}$

${ }^{a}$ School of the Built Environment, University of Reading, UK.

i.j.ewart@ reading.ac.uk *corresponding author 


\title{
The social consequences of minor innovations in construction
}

\begin{abstract}
Innovation studies in construction are dominated by a desire to increase economics and efficiency at a large scale. This has resulted in a skewed perspective that sees only major corporations with substantial $\mathrm{R} \& \mathrm{D}$ resources, complex projects and national interests at the heart of innovation. By adopting an ethnographic approach, it becomes possible to examine the two aims of this paper: to demonstrate that an accumulation of minor innovations can have significant consequences; and to show that these are inherently social rather than purely economic. Results come from fieldwork studying the house-building practices of the Kelabit people of rural Borneo, tracing changes to the technologies used for roofing and foundations, and describe how these are mutually entangled with new social structures. The conclusion is that we should think more broadly about the forms and effects of innovation in construction.
\end{abstract}

\section{Keywords:}

Innovation studies; minor innovations; Kelabit; house building; social change.

\section{Introduction: Innovation in Construction}

The process of innovation in the construction sector has given academics much to write about in recent decades, primarily interested in how innovations can contribute to increased efficiency and the problems associated with achieving them in practice. Most of the academic research on the subject uses as its starting point key government reports from the 1980s and 90s, which suggested that the construction sector was ripe for improvement and in need of a change in attitude (Latham 1994; Egan 1998), a widely held belief that has persisted (e.g. Carrillo and Chinowsky 2006). And whilst this portrayal of the sector has been questioned quite convincingly in a number of ways - by considering forms of management (e.g. Green et al. 2005), comparisons with other sectors (e.g. Winch 2003), or organisation size (e.g. Sexton and Barrett 2003) - there is a general acceptance that innovations in construction are difficult to categorise and equally difficult to quantify. The root cause of these difficulties is the 
heterogeneous nature of construction projects and the fragmentation of the sector (Harty 2008) as well as "sector-specific demands" including health and safety, global competition, unpredictable markets, shifting economics and environmental agendas (Holt 2015:258). Such complexity and ambiguity in working practices means that defining innovation is difficult since what can be considered to be 'innovative' falls foul of the problems attempting to separate out each sub-section of a complex and economically large industrial sector.

Perhaps because of these difficulties, the dominant rhetoric in discussions of innovation in construction tends to be at the macro-level: government policies, large contracting firms, major projects and so on. For example, Xue et al. in their review of construction innovation research, list the three innovation outcomes as: industry efficiency, corporate performance, and sustainability (2014:119-120). As Hirsch-Kreinsen rightly points out this skews the argument in favour of larger corporations able to spend on R\&D (2008), or those able to comply with policy makers' need for a scientific approach (Trippl 2011). It also generates an appetite for headline-grabbing initiatives that are seen (or hoped) to be the centre of a step-change that diffuses around the industry.

There is little consideration of the minor innovations that occur at the hands of skilled individuals, whether working on-site or in an office, that can accumulate to create a significant effect. Each individual small-scale innovation is apparently unremarkable when viewed in isolation, and hence garners few column inches. So here I will follow authors such as Hirsch-Kreinsen, and Trippl, in suggesting that a focus on the innovations of larger firms or industries with a scientific-experimental approach is not the only way of looking at the issue. We can also see that "practical knowledge is generated in application contexts of new technologies and obeys validity criteria such as practicability, functionality, efficiency and failure-free use of a given technology" (Hirsch-Kreinsen 2008:27). Or Trippl's description of the continuous smaller innovations in the Viennese food sector: "Skilled workers, learning by doing and using, as well as learning by interacting...play a crucial role" (2011:1601).

If we step back and look for the coalescence of these minor changes, we can see how an accumulation of incremental innovations (Hirsch-Kreinsen 2008:24-26) creates an effect greater than the sum of their parts. The difficulty lies in the seeing: small things that by themselves cannot justify their own chapter or paragraph in a white paper or industry report, need a particular way of looking that can expose and understand their significance. So I suggest we can see better by adopting an anthropological perspective, in that it pays attention to details of beliefs and behaviours in different cultural settings. 
In recent decades, the anthropologists' roving eye has switched its attentions beyond its early traditions of remote exoticism, and been trained on the cultures and sub-cultures of Euro-America, so that even the construction industry itself has begun to be scrutinised ethnographically (e.g. Pink et al. 2012). At the same time as recognising the 'exotic other' to be as much in our midst as outside, those that were once exotic are now seen without the same patronising attitudes, and recognised as being as relevant to modern culture as any other. I make this point as a prelude to the case study that will be discussed in more detail later in the paper: The Kelabit people from the rainforests of highland Borneo, and their adoption of non-traditional construction materials and techniques. The Kelabit are a remote rural community, and the construction methods and projects they undertake are not of the same scale and complexity as the type of case study quoted by, for example, some of the authors cited above. However, their traditions of resourcefulness are reflected in their attitudes towards the development and adoption of new materials and techniques of construction, and illustrate the consequences of what might be seen on the surface as lowlevel innovations.

This leads me to another point of difference with the traditional literature on the diffusion of innovation. By taking the unit of analysis from the structure of the sector, usually at the level of corporations or projects, current ways of thinking about innovation and diffusion largely ignore the societal level, let alone the social consequences. Considering the economics of the sector - increased profits, economic growth etc. (e.g. Robertson and Patel 2007) - as the primary influence on its societal impact, there is a tendency to see large scale projects as socially enabling or disruptive, while missing the significant impact that smaller scale changes have made to a wider range of people. This is sometimes mentioned in the literature, but not given any degree of prominence. For example, Warnke et al. briefly discuss 'Social Innovation' and conclude that “Innovation in social practices and in particular those that are not primarily aiming at market introduction are not recognized by the established system" (2016:10), but by limiting their thoughts to social practice innovations, they do not seriously consider technological innovations at a small scale. Minor innovations are not simply changes in behaviour, they are changes in materials, tools and techniques that can have a significant social effect. Similarly, whilst Robertson and Jacobson recognise that modest changes can have major consequences (2011:6), they limit this to economic value, apparently on the basis that the effects are important only when applied to corporations, nations or whole industries. And Xue et al. begin their review by stating that "Innovation, making a significant contribution to domestic economic growth, being important in 
competition, and significantly improving the quality of life, has been regarded as the core of a knowledge-based economy" (2014:111), and from then on scarcely mention anything related to quality of life. From their reading of the literature on innovation in construction, even the idea of sustainability, which is generally held to have a social component as one of its three main pillars, is reduced to issues of corporate effectiveness.

To offer a counterpoint to these macro-level units of analysis with their single-minded pursuit of the next major shift in technology, policy or practice, I will instead adopt a perspective at the level of a small-scale society. I also unapologetically consider particular materials and techniques as innovative, despite the fact that to many readers they will be simple and mundane. The data presented comes from a period of fieldwork in rural Borneo, observing and participating in the engineering activities of a community inhabiting the highland interior known as the Kelabit people. Covering the period 2008 to 2010, this included numerous visits to the Kelabit highlands, particularly to the village of $\mathrm{Pa}$ 'Dalih, and time spent investigating Kelabit culture in larger towns in Malaysian Borneo, especially Kuching and Miri.

So, to summarise, I have two aims in this paper: first, to suggest that innovations seen at the macro-level with a 'step-change' mentality are incomplete and potentially unhelpful; and second, to show that the consequences of innovation are not just economic or political, they are inherently and significantly social.

\section{An Introduction to the Kelabit ${ }^{1}$}

The Kelabit people of Borneo number around 5,000 with a traditional homeland in the northern interior highlands on the border between Malaysia (Sarawak) and Indonesia (Kalimantan). The earliest European contacts were at the turn of the $20^{\text {th }}$ century when a mix of Christian missionaries and British colonial administrators sought to bring indigenous peoples into line with their systems and ways of thinking. The Bornean highlands were at the time remote and difficult to access, around $200 \mathrm{~km}$ from the populous coastal towns that were rapidly expanding on the back of trade between Asia and Europe. Travellers to the highlands were faced with an arduous journey lasting several weeks down treacherous rivers and over

\footnotetext{
${ }^{1}$ This brief summary is taken largely from Janowski (2003), and Ewart (2009), both of which include many more references for those wishing to find out more.
} 
steep and wet mountainous terrain. The demand at the time was jungle products such as camphor used in the manufacture of plastics and paints, and rubber to satisfy the demands of the emerging automotive industry. In return, the Kelabit were given the protection of the British military in their constant inter-tribal struggles, and a belief system to replace their traditional forest spirits. Contacts with the industrial world continued and increased through the $20^{\text {th }}$ century, gathering pace when the highlands were used during WW2 as a base for British and Australian paratroopers, who offered the Kelabit an alternative version of western Christianity to the pious and officious missionaries they were used to. More importantly for the discussion here is the fact that along with these troops (and to a greater extent the larger numbers who arrived in the 1960s during the confrontation between Malaysia and Indonesia), came quantities of products from the West, including industrially manufactured materials, which were readily adopted as building materials.

The Kelabit were by then undergoing societal changes that included a move away from a lifestyle based on itinerant swidden agriculture, where areas of the forest were farmed for about five years then the village moved a few miles to a new area (Janowski 2003:29-34). Over the course of the next few decades, families coalesced around semi-permanent rice fields created by altering river courses, and the temporary structures that were traditionally built started to become more permanent. This was at a time when access to shop-bought goods was starting, first through the military grass-strip airfield with subsidised flights to Miri, and then in the early years of the $21^{\text {st }}$ century with the encroachment of commercial logging in the Kelabit Highands, reaching the immediate vicinity of Pa'Dalih in around 2005. Commercial logging licenses were granted by area, with an agreed number and types of tree to be removed, before the loggers moved to the next area. Whilst the activity of removing the trees was itself destructive and controversial (Tsing 2005), even more so were the roads cut indiscriminately between logging areas to allow the heavily laden trucks access between the rural interior and coastal towns like Miri. These roads covered a larger area than the actual areas being logged, and caused constant problems of soil erosion and excessive silt in river water, as well as encouraging the movement and proliferation of rats. As the head man of Pa'Dalih in 2009 said "last year we farmed two fields of rice for us and one for the rats; this year we have one field; next year we will be rat farmers."

However, the logging roads were seen by local people in a generally positive way, since they connected distant communities and allowed access for the first time between the highlands and Miri by vehicle. The roads themselves were little more than broad mud tracks, constructed by simply bulldozing a vaguely flat section into the mountainside and crossing 
the many streams with shanty bridges made of large trees dragged out of the nearby forest. Heavy rains and lack of any form of reinforcement often caused localised landslides and made the roads impassable, especially when the logging companies had moved on and no longer had any reason to maintain them. Despite this, with characteristic ingenuity, the Kelabit were always able to clear obstacles or create even more perilous alternative tracks over or around the collapse. For the visitor, this makes for a harem-scarem 10 to 15 hour truck drive from Miri to Pa'Dalih, especially after dark when the slippery mud surface and nearness of the precipitous drop play on the mind and grow increasingly terrifying. But 4WD trucks were able to get through and load up with half a tonne of whatever the world had to offer, including materials that had been seen only rarely in villages like Pa'Dalih, enabling innovations in construction and playing an important role in the social realignment that was happening at the time.

As with the need for periodic communal labour in the agricultural cycle, the Kelabit system of organised labour, kerja sama, where groups of villagers will come together to carry out other larger scale projects, helping one another on the understanding that the favour will be returned. So, during the planting season, each family's fields would be worked in turn by most of the community, and the same system would be traditionally used to do things like rebuild the longhouse, or build and maintain bridges and roads (Ewart 2013). This was especially important, even vital, when swidden agriculture was the dominant form of subsistence farming, as the whole of the longhouse and all its human, animal and material contents would be physically carried through the forest, and reassembled a few miles away.

\section{Traditions of house-building}

To discuss and highlight the innovations in construction that took place in rural Borneo in the early $21^{\text {st }}$ century, it is worth describing the systems of construction that were traditionally common and have been recently disrupted. In particular, the construction of houses (see also Ewart 2013 for descriptions of innovation in Kelabit bridges) and the socio-material changes that have recently taken place. As swidden agriculturalists, the Kelabit built houses that met their needs for a period of up to around 5 years, before being dismantled and transported several miles along jungle paths to the next location, then 5 years later the next, and so on until they eventually returned to the first site several decades later. Village groups, up to perhaps 100 strong, would live in a single building, the iconic longhouse, with each family responsible for their own section of the building, but within a system of communal labour (known as kerja sama), where the whole village was asked to help with major works. The 
Kelabit longhouse was traditionally a single long building raised on stilts and divided longitudinally into two main areas, the family and sleeping area (tawa), and a social area (dalim) with the feeling of something like a busy covered street. These two areas were connected by a series of footbridges, so that each family unit typically had a 'slice' of the longhouse with a private area, a bridge and a social/cooking area (Janowski 2003).

Up until the 1980s, the construction of Kelabit houses remained largely traditional, with the exception of the corrugated metal sheets. Palm thatch roofing was largely extinct, except on temporary huts in the forest used during hunting trips, and the tin roofs had become the new 'traditional' way of building. The original part of the Pa'Dalih longhouse, constructed in the late 1970s would have felt very familiar to the grandparents of the current villagers, and not too unusual to their grandparents as well (Figure 1).

Figure 1: Interior of Pa'Dalih longhouse, late 1980's

There were two key influences on the choice of materials, one social and the other practical. Practically speaking, the house had to last only the typical 5-year cycle, and would need to be able to be broken down and transported by hand. This meant that readily available materials such as palm leaves would be collected at each new site, and heavy materials would be avoided where possible. Bamboo is durable enough to last several years, but plentiful enough to make it easy to collect and is still commonly used as a building material in bridges and temporary structures and until recently was a common material for walls, screens and sometimes flooring. On the other hand, before the introduction of power tools, processing hardwoods by hand was a time-consuming activity, so most of the wood was used in such a way as to preserve it for several house-building episodes. The wide floorboards, made from local hardwoods were kept as thin as possible to make them lighter and easier to transport, and even the best quality locally available hardwoods were susceptible to rot in the rainforest climate, so were mounted on stone foundation pads by way of mitigation. The foundation stones were available along the many nearby river beds, so would either be collected anew or left in situ for the duration of a complete swidden cycle, when the village returned possibly decades later.

Certain material choices, especially the wooden floorboards, also came to denote social standing, since their production required the substantial time, effort and skill of several 
villagers and high quality metal tools, resources that were more likely to have been available to the senior members of the community. Even when the village had several petrol-driven chainsaws, and cutting up trees for planks was done en masse, specific very old floorboards were still talked about with pride, and often used as the starting point for historic stories and family legends - grandfathers who had carried that particular piece of wood from one location to the next, and handed it down as a valuable heirloom. The older floorboards could be recognised by their distinctive fish-scale appearance created as the surface was finished with an adze (like an axe but with the cutting edge parallel to the floor), which, along with admiration for the widest boards, set them and their owners out for special attention (some of the floorboards visible in Fig. 1 are well over 100 years old). Further social standing came with the enthusiastic uptake of some of the materials that had begun to trickle in with the troops from WW2 and the Confrontation in the 1960s, demonstrating both economic power in obtaining them, and social influence in gaining access to a scarce resource. As with the other important materials, particularly the floorboards, corrugated metal roofing sheets were re-used many times, and many are still in place in the current longhouse in $\mathrm{Pa}$ 'Dalih, where thin shafts of sunlight pierce the smoky gloom through nail holes made in past fixings. By the turn of the $21^{\text {st }}$ century however, new materials and techniques were changing the construction habits of Kelabit house-builders, and it is to these innovations that I now turn.

\section{Minor Innovations}

For the Kelabit, innovations in construction have come about in recent years as a result of the development of transport links, especially the network of logging roads, and the availability of satellite TV and internet connections. These connections to the wider world are still somewhat fragile and unreliable, but are becoming more stable and dependable, and have allowed remote communities to experience a huge range of new possibilities. Many of the younger men in villages like Pa'Dalih split their time between working in the wage economy, usually in the oil industry based on the northern coast and offshore areas of Borneo, including the Kingdom of Brunei, and through Australian multi-national corporations. Access to these areas has been much easier with the gradual encroachment of logging roads northwards and further inland, altering forms of movement to and from Pa' Dalih, from walking to scooters to 4WD trucks. Off-road motorbikes are now quite common and there are several Toyota trucks bought with the proceeds of wage labour. As well as transporting people away from highland villages, these larger vehicles are also returning with new objects, materials and ideas that were until very recently quite alien to the villages and their occupants, and have had 
significant consequences for the main activities of the villagers. Primarily these are agriculture and building, both of which have been substantially altered: the introduction of preserved foods supplementing and replacing some of the subsistence crops, and the availability of materials and tools has changed traditional methods of house-building.

To illustrate the interdependencies of these technological and cultural changes I will give two examples of minor innovations in housebuilding that have been part of an accumulated change with quite profound social impacts. First the changes to roofing, as the Kelabit moved away from their itinerant lifestyle to longer-term settlements; and second the introduction of cement as a new material and its on-going effects in enabling durability and hence reducing the need for maintenance work, traditionally the role of men.

\section{Roofing: From thatched palm leaves, to painted and insulated aluminium.}

As we have seen, the Kelabit longhouse rapidly switched from the traditional palm leaf thatched roof to the corrugated metal roof. Indeed, this happened at a time when it was still usual for the village to move periodically, and so the roofing sheets would be removed and carried on to the next stop, then re-installed. Many of these sheets were donated by departing troops, first at the end of WW2, and then in the late 60s at the end of the Confrontation, so did not require cash or travel to acquire them. Explaining why the Kelabit adopted corrugated steel roofing so enthusiastically is not straightforward, nor is the fact that this seems to be almost universally true in rural communities (see Waterson 1990). In truth, as a roofing material in a climate of hot sun and heavy rain, tin roofs suffer from at least two significant disadvantages. When the sun is out, the roof radiates heat down on the occupants to a degree that is beyond uncomfortable to the casual visitor, especially when combined with the long row of hearths and constantly boiling pots of rice. When it rains, the tropical downpour clatters with such force on the roof that it is impossible to hear someone talk, so people either sit close together, or refrain from conversation at all. Talking to many of the older villagers in $\mathrm{Pa}$ 'Dalih, they would lament the demise of the thatched roof, which had neither of these problems, and also allowed woodsmoke to seep out more easily than the ineffective chimney openings in the metal roof. It should be said that this was a somewhat romantic view of the past and usually sparked a debate about how dirty the thatch was, and how it harboured insects and needed constant repair. The simple explanation is that the metal sheets are more durable and once fixed they can essentially be left alone for many years, but there is a social aspect to this as an innovation in construction practices. For the Kelabit and many such small-scale societies, there has been until very recently a ready disavowal of their past 
traditions, for fear of being seen as backward. This began with their animistic belief system being replaced with Christianity (for the Kelabit this happened in the 1960s and 70s), and a consequent and enthusiastic admiration for the Western way of life, especially the philosophy of a correlation between technological and social advancement.

As Lemonnier (1993) has described, technological choices are as much to do with socio-cultural traditions as material attributes, so the enthusiasm for metal roofing sheets was as much to do with attempts to demonstrate modernity as it was to improve the longhouse roof. That was in any case difficult to justify in the light of the compromises that had to be made - they were less effective, more difficult to use, and limited in supply. However, an almost-unintended consequence of the use of metal sheeting was that roofs became more durable. This was happening at the same time that agricultural practices were changing as the Kelabit developed semi-permanent padi fields by diverting or using natural water courses to provide irrigation (Janowski 2003:29-34). Quite how these two trends to permanence are related is difficult to say, but permanent settlements were more conducive to durable houses, which changed the housing requirements of the community, which in turn reduced the maintenance burden on the village, especially the men.

In Pa'Dalih the approach to roofing materials is still developing. The older corrugated steel sheets have been replaced to a large extent by lighter aluminium, so that more sheets can be brought back from Miri, along the logging roads on the back of a truck. These were found to be less resilient to the hot, wet climate in the highlands, so aluminium sheets are now commonly painted, either by hand on site, or bought in as pre-coated sheets. The issues of thermal and acoustic insulation are also being addressed, in at least two ways. Some buildings now have a false ceiling installed, creating an insulating buffer between the hot metal and the rooms below, and more recently some Kelabit have experimented with rolls of fibreglass insulation, fixed to the underside of the metal roof sheets with wire mesh. This idea, although quite effective, was met with considerable scepticism since it was seen as a step back to the days of thatched roofing, when the roofing material became infested with insects that damaged objects made from local materials. The Kelabit, until very recently, relied heavily on containers made from natural materials, especially woven baskets, which were highly susceptible to insect attack. Although basketry is still an important activity, there are many more metal and plastic containers, so the effects of any insect infestation is likely to be limited. However, this observation on its own was not enough to convince the majority of the villagers, most of whom reserved judgement until the new insulation had proved itself. 


\section{Foundations: From stones and wood, to concrete and steel.}

Developments in roofing aside, there have been many other minor innovations in Kelabit construction techniques, including my second example: changes in foundations and structural supports. The traditional technique was to source hardwoods from the surrounding secondary forest as the main structural members, which are then given some protection by mounting them on large stones as foundation plinths (as in Fig. 2a). The stones and wood were easy to find and the wooden structure could be taken apart and moved after a typical five-year swidden period. With a move towards permanence and greater access to more distant places, a regionally available hardwood, known as 'ironwood' (belian), began to be used from about the late 1990s. This could be set into the ground and would last a decade or more. However, ironwood is expensive and in limited supply, depending primarily on local politics, so remained a rare commodity. To keep requirements to a minimum, a small section would be used as the supporting foundation for the house, grafted onto local hardwoods for the bulk of the upper structure (see Fig 2b).

More recently, the Kelabit have started to think about how they could improve on this with another new material - concrete. Of course, concrete is not an innovative material per $s e$, but in the context of the construction traditions of this specific community, the difficulties of acquiring cement, which was extremely rare in the highlands until the early 2000's, meant that it was a new material with new possibilities for the Kelabit. Having the raw material is not enough on its own, there have to be the associated knowledge, skills, tools and techniques to be able to use it, and the communal will to make it socially acceptable, something still in progress for concepts of roofing insulation as described above. For the villagers of Pa'Dalih, knowledge has arrived primarily through the experience of the men who have travelled to the coast for paid labour. Many of them worked in the oil industry, but as that industry expanded, so too did a whole range of auxiliary industries in particular, for this discussion, shops and construction. One of the men from $\mathrm{Pa}$ 'Dalih had gained experience of housebuilding in and around Miri, whilst several others had worked in the oil industry, so there was a growing awareness of the potential for new materials and greater access to cash with which to buy them, cement in particular.

The environment in the Kelabit highlands is heavily forested with numerous rivers, some of which are quite large and produce prolific quantities of sand and stones, ready to combine with cement to make concrete. So once the villagers were able to purchase and transport quantities of cement and had acquired some knowledge about how to use it, when combined with locally available resources the Kelabit embraced concrete as an alternative to 
some of the traditional materials and techniques used in building their houses. By 2008, a concrete playing area had been laid for the volleyball court, some of the main paths and communal areas in the village were being re-laid in concrete, and concrete was being used to set and support wooden structural elements of the larger buildings. Where these had once been local hardwoods standing on stone pads, then ironwood base posts grafted to a main structure of locally sourced wood, which were latterly set in concrete footings, the latest innovation is to use a concrete and steel foundation onto which the wooden structure is bolted (Fig 2c).

Figure 2a - Local hardwood supported on stone pads

Figure $2 b$ - Ironwood grafted to local hardwood

Figure $2 \mathrm{c}-$ Concrete and steel footings

As with the roofing insulation, the steel foundation plates are yet to be widely accepted for reasons of cost and the lack of metalworking knowledge. Firstly, there is the cost of transport since they would need to come from Miri and weight is limited on the trucks that periodically drive back and forth; and secondly, unlike using wood as a material, there are limited traditions of metalworking in the Bornean interior. So while it is quite common to see modern tools for processing wood, such as chainsaws, drills and electric planes, there are not the equivalent tools or skills available to produce metal components, or knowledge of the limitations of the material. Despite this, the drive to producing ever more durable housing means that the difficulties of using these new materials are being tested and gradually overcome, and metal components are being trialled in a number of uses in Kelabit construction including houses and bridges (Ewart 2013).

The two parts of the house described above (the roof and foundations) are perhaps the parts most susceptible to deterioration, so it is perhaps no surprise that they have been the focus of ongoing innovative practices. A thatched palm roof needs replacing after a few years, whereas a painted aluminium roof will last for decades; a locally sourced wood and stone foundation would need maintenance after a few years, whereas a raised concrete/steel footing, bolted to local wood will also last for decades. The complex interactions that have enabled and driven these changes - the desire for durability to allow men to leave the village to enter the wage economy - have created a series of minor innovations that have 
accumulated to the point where new traditions of house-building are affecting house structures, which are in turn affecting the social structure of the Kelabit village. It is those social consequences that I turn to now.

\section{The Social Consequences of Innovations in Construction}

When reading the academic literature on innovations and the diffusion of knowledge, it is hard to escape the impression that the only real consequence is an economic one. The majority of authors see the effects of innovation on the performance of corporations or changes to government policies, with a heavy emphasis on improving profits and increasing efficiencies of production and management (e.g. Xue et al. 2014; Robertson and Jacobson 2011; Trippl 2011). With an anthropologist's perspective it is clear that there are other consequences to changes in practice that are cultural and social. However, although the examples I have given here are based on a small-scale community, it would be wrong to dismiss this as a minor historical interlude, where this remote group are 'catching up' with the rest of the world - they have for generations been pursuing their traditions of housebuilding, and over time have adapted to changing social environments in much the same way as any other culture. The introduction of materials such as metal roofing sheets and cement, and the way these have been incorporated into and influenced the changing Kelabit social and physical architecture, is merely an illustration of the process of incremental innovation and the wider social consequences of new practices.

For the Kelabit, innovations in construction go hand in hand with new forms of social organisation: neither would be possible without the other. As the Kelabit moved away from their tradition of swidden agriculture and their villages became fixed in the landscape, the construction criteria for the house changed over time too (Ewart 2012). Houses needed to become less dependent on male labour to repair and maintain for the months when they were absent; there was no longer any need to rely solely on locally available materials of construction; and the houses were no longer constrained by the traditional need for them to be easily disassembled and physically carried long distances through difficult terrain.

Conversely, the migration of men to coastal towns for paid labour is enabled by the durability of the houses that they would otherwise be responsible for maintaining. This co-dependency between patterns of migration and innovations in construction has had a parallel change in the social structures as well as the physical ones. Communal living was inescapably dependent on communal construction in the era of temporary longhouses: time was relatively short and for the most part, the village had to stay together to carry out their reconstruction 
activities. Whilst each family was responsible for their own section of the longhouse, it was down to the community through the kerja sama system of organised communal labour to gather together the skills, tools and labour needed to rebuild the longhouse in its new location.

Perceptions of durability were based on the need for buildings to last those few years, so materials and techniques of construction, and systems of maintenance were adopted accordingly. This was disrupted by a confluence of circumstances in the latter decades of the $20^{\text {th }}$ century: discarded military materials, logging roads reaching further into the interior, and the tantalising adventure of waged labour. But pulling against this was the need for enough people to engage in kerja sama and carry out the communal tasks of agriculture and construction. A system of communal labour can still function if one or two young men leave for a few months, but there comes a point when the population of the village is too heavily dependent on the women, the children and the elderly to make it sustainable. This might have been the case for the Kelabit but for their appropriation of innovative construction technologies, not as an answer to existing technical problems, but as an ongoing evolution of cultural practices to suited the social environment. This is an example of what anthropologist Gisela Welz refers to (borrowing the phrase from Ulf Hannerz) as "the cultural swirl" (2003). Innovation is not dependent on a skilled or charismatic individual per se, but depends on the social milieu of which those people are a part, and "seem to function best when they join heterogeneous social actors and are not closed systems but exposed to serendipitous encounters and exchanges with other outside actors..." (2003:266).

As a result of the development of houses that require less maintenance, the tradition of the longhouse, historically dependent on the need for a community to share responsibility for its construction and upkeep has also started to fracture. By 2008 the main longhouse in Pa'Dalih was half empty, as some families were spending more time away in Miri and the need for kerja sama was reduced by the same materials and technologies that enabled the men to spend several months away from the village. Without the need for organised communal maintenance, and a greater availability of cash to pay for labour, more durable housing meant that the general architecture of Kelabit housing has significantly changed in the last two or three decades, moving away from a single longhouse to individual housing. The longhouse is no longer at the heart of the village as more families move to an individual house, freed from an obligation to contribute to maintenance by the construction of their own maintenance-free house. The evolution of architecture began with some families recreating their slice of the longhouse (sometimes by dismantling and re-using materials from their 
section), with the private area (tawa) still connected to the pubic area (dalim) by a footbridge, but built on a separate plot within the village. As the longhouse empties, or fills temporarily with visitors and Indonesian teachers, the fracturing of the longhouse is seen by some as a metaphor for the fracturing of the Kelabit sense of community. Even the wife of the headman, in their large house on the banks of the river, would reminisce about times living in the longhouse when she felt intimately connected to the community.

And the social, technological and architectural evolution continues. Figure 3 shows a new house under construction that illustrates many of these points. It is the house of a single family, who were still resident in the secondary village longhouse, but were building their new home on the outskirts of the village near their padi fields. The roofing is a green painted metal sheeting, with insulation fixed to the underside, the windows are glass (another recent innovation), and the ground floor has a concrete slab. The foundation system is a raised concrete footing with metal plate (Fig. 2c), onto which are bolted locally sourced (and machined) wooden structural members. The design itself departs from Kelabit tradition, inspired by Alpine lodges, with multiple steep roof pitches and an upper storey: the Kelabit admire the beauty of the Alpine region and it is not uncommon to see tourist posters from Switzerland decorating interiors.

Figure 3: New house under construction adopting many of the innovations described.

This move away from the traditional longhouse is not universally welcomed, not least because of its continuing role as a place for convenient social and political interactions. Village meetings and celebrations are usually based around the longhouse, and the position of individual family units is a marker of their status, with the headman traditionally at the centre. The Pa'Dalih longhouse was becoming less important for these roles, as some senior family members were spending more time away from the village, and the headman himself often held social and political meetings in a large open area of his own multi-storeyed house. Greater numbers of non-Kelabit had also moved into the village, in part because the local school was there, which drew in various people from around the region and teachers from further afield in Malaysia and Indonesia, some of whom were housed in a rented family unit within the longhouse. This had the effect of altering the patterns of behaviour and social interaction within the longhouse - for example religious differences often prevented 
neighbours from eating the same food or at the same time. Social activities were generally smaller and less spontaneous.

Of course, I am not suggesting that the development of these new social structures was based entirely on more durable houses. There are other causes including the access to transport links, the migration of men to a waged labour, increasing influences from the outside world, the end of inter-tribal violence and so on. However, it is impossible to escape the conclusion that without this gradual accumulation of minor innovations within the cultural swirl, the conditions that enabled these consequences would not have occurred. Perhaps some other conditions would have come about that would have caused the same or similar consequences; it seems likely that links to the industrial world would develop along one pathway or another, but the fact is that it is this pathway that has come about, and the enabling factor has been the introduction, understanding and appropriation of new materials and techniques of construction, satisfying the need for more durable housing. The social consequences are yet to be fully played out, and the slow death of the longhouse may be mourned by some, celebrated by others, or even ultimately reversed. But the process continues, perhaps with a shift away from the pursuit of increasing durability to include now issues of comfort and aesthetics, and new architectural forms that will need to accommodate a changing Kelabit socio-cultural structure. We can however be sure that the accumulation of minor innovations in construction, and the future shape of this society and many others, are mutually entangled, composing and composed by one another.

\section{Acknowledgments}

Fieldwork was carried out as part of an ESRC Doctoral Studentship from the University of Oxford, Institute of Social and Cultural Anthropology, 2007-2011.

\section{References}

Carrillo, P. and Chinowsky, P. (2006) Exploiting knowledge management: The engineering and construction perspective. Journal of Management in Engineering, 22(1), 2-10.

Egan, J. 1998. Rethinking Construction: Construction task force report for the Dept. of the Environment, Transport and the Regions. London: HMSO.

Ewart, I.J. 2009. The documented history of the Kelabits of northern Sarawak. Sarawak Museum Journal, 66(87): 229-257.

Ewart, I.J. 2012. The social and material influences on the Kelabit dwelt environment.

Traditional Dwellings and Settlements Review, 23(2):69-82. 
Ewart, I.J. 2013. Designing by doing: Building bridges in the highlands of Borneo. In Gunn, W., Otto, T. and Smith R.C. (eds.) Design Anthropology: Theory and Practice, pp.85-99. London: Bloomsbury.

Green, S., Fernie, S. and Weller, S. 2005. Making sense of supply chain management: a comparative study of aerospace and construction. Construction Management and Economics, 23(6): 579-593.

Harty, C. 2008. Implementing innovation in construction: Contexts, relative boundedness and actor network theory. Construction Management and Economics, 26(10): 1029-141.

Hirsch-Kreinsen, H. 2008. "Low-Tech" innovations. Industry and Innovation, 15(1): 19-43. Holt, G.D. (2015) British construction business 1700-2000: proactive innovation or reactive evolution? Construction Innovation, 15(3), 258-277.

Janowski, M. 2003. The forest, source of life: The Kelabit of Sarawak. London: The British Museum occasional paper no. 143.

Lemonnier, P. 1993. Introduction. In Lemonnier, P. (ed.) Technological choices:

Transformation in material cultures since the Neolithic, pp:1-36. London: Routledge.

Latham, M. 1994. Constructing the team: Final report of the Government/industry review of procurement and contractual arrangements in the UK construction industry. London: HMSO.

Pink, S., Tutt, D. and Dainty, A. (eds.) 2012. Ethnographic research in the construction industry. London: Routledge

Robertson, P.L. and Patel, P.R. 2007. New wine in old bottles: Technological diffusion in developed economies. Research Policy, 36: 708-721.

Robertson, P.L. and Jacobson, D. 2011. Knowledge transfer and technology diffusion: an introduction. In Robertson, P.L. and Jacobson, D. (eds.) Knowledge transfer and technology diffusion, pp.1-34. Northampton, MA: Elgar.

Sexton, M. and Barrett, P. 2003. A literature synthesis of innovation in small construction firms: Insights, ambiguities and questions. Construction Management and Economics, 21 (6): 613-622.

Trippl, M. 2011. Regional innovation systems and knowledge-sourcing activities in traditional industries - evidence from the Vienna food sector. Environment and Planning A, 43: 1599-1616.

Tsing, A.L. 2005. Friction: An ethnography of global connection. Princeton: Princeton University Press. 
Warnke, P., Koschatzky, K., Donitz, E., Zenker, A., Stahlecker, T., Som, O., Cuhls, K. and Guth, S. 2016. Opening up the innovation system framework towards new actors and institutions. Fraunhofer ISI Discussion Papers Innovation Systems and Policy Analysis, no.49. Fraunhofer ISI, Karlsruhe.

Waterson, R. 1990. The living house: An anthropology of architecture in south-east Asia. Oxford: Oxford University Press.

Welz, G. 2003. The cultural swirl: anthropological perspectives on innovation. Global Networks, 3(3): 255-270.

Winch, G. 2003. How innovative is construction? Comparing aggregated data on construction innovation and other sectors - a case of apples and pears. Construction Management and Economics, 21(6): 651-654.

Xue, X., Ruixue, Z., Yang, R.J. and Dai, J. 2014. Innovation in construction: a critical review and future research. International Journal of Innovation Science, 6(2): 111-125. 


\section{Figures}

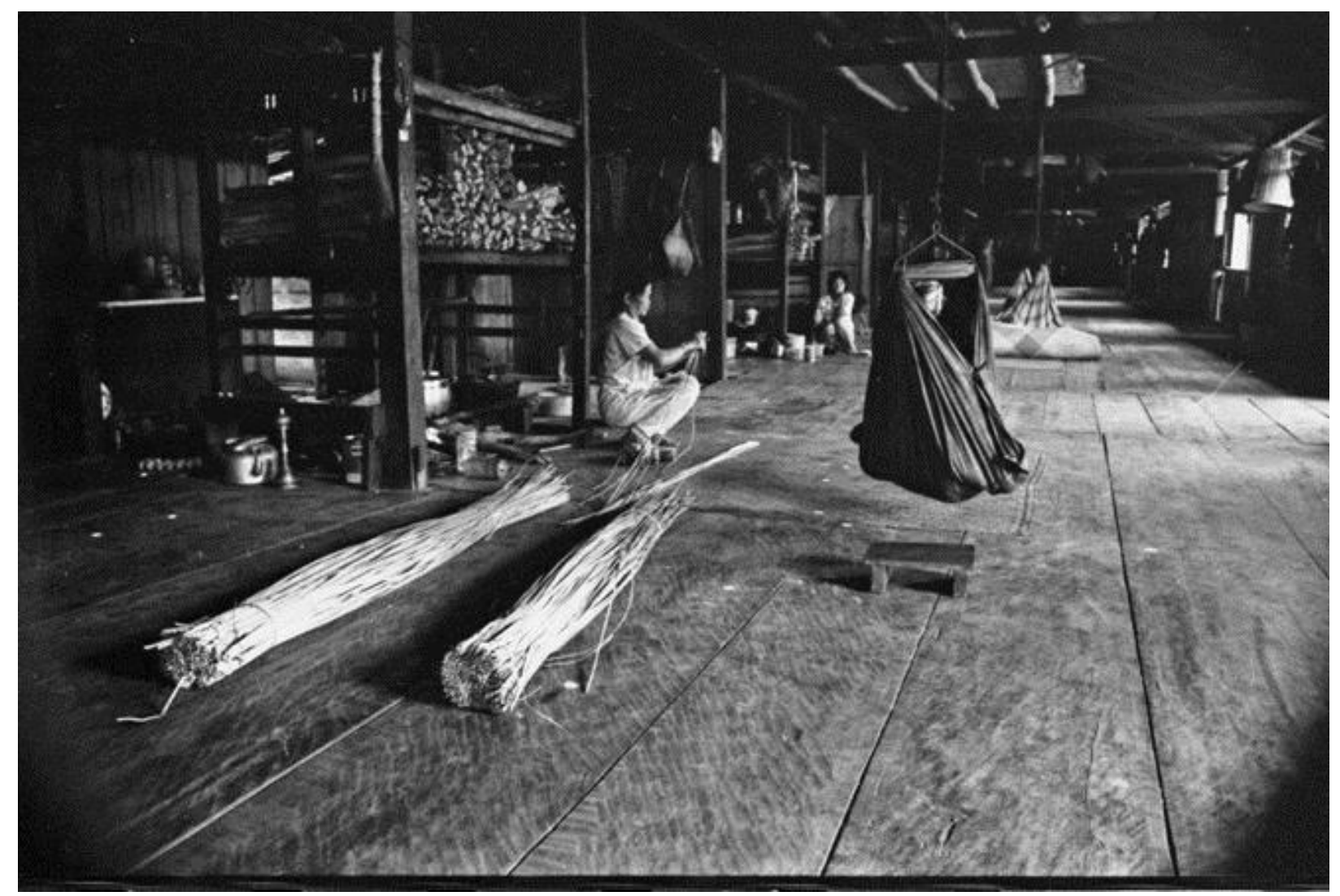

Figure 1: Interior of $\mathrm{Pa}$ ' Dalih longhouse, late 1980s. Floorboards in the foreground have the distinctive surface finish of the adze cut boards, and are perhaps 100 years old (Photo by Kaz Janowski, (C) Monica and Kaz Janowski) 


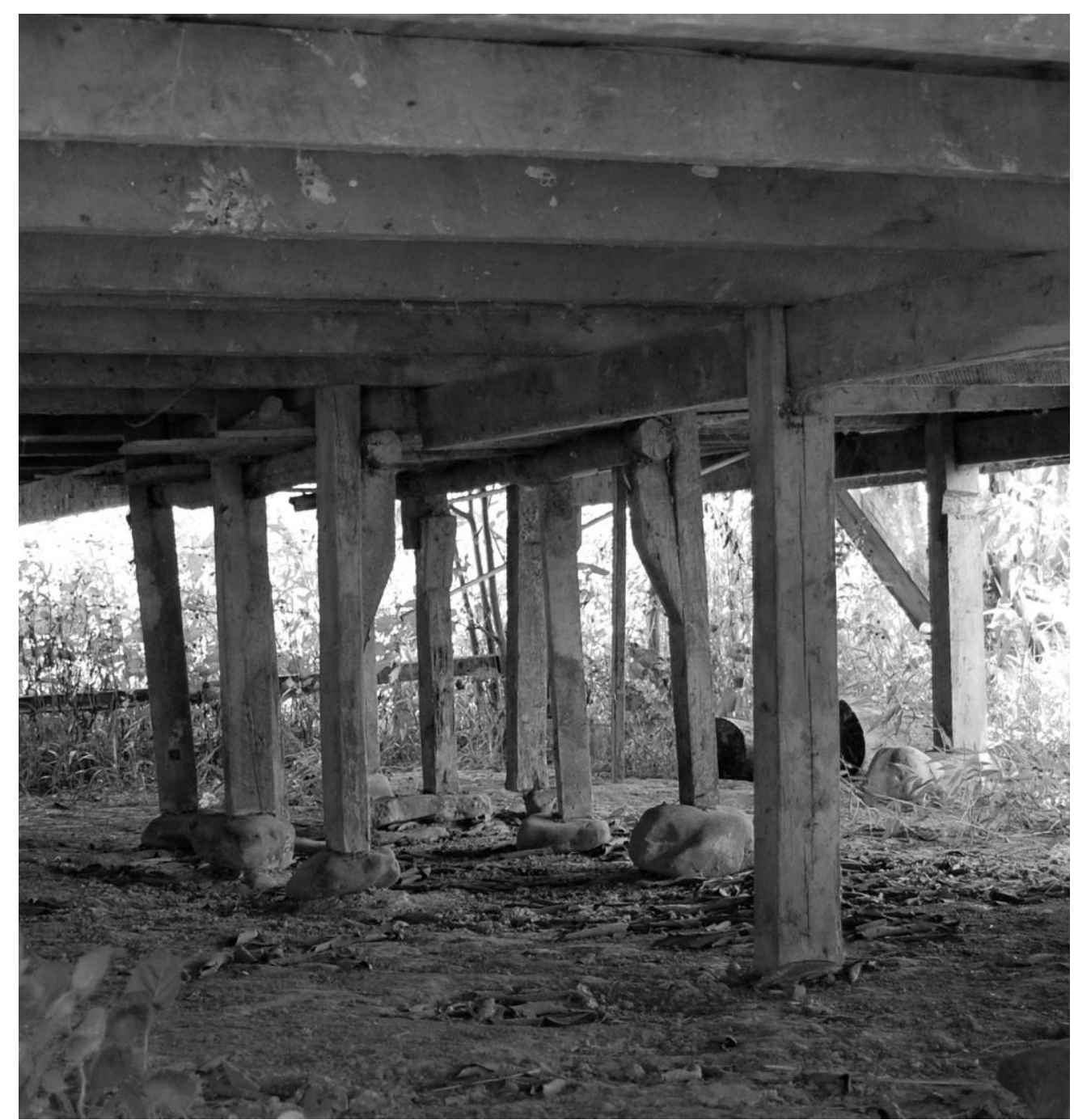

Figure 2a: Local hardwood structures mounted on plinths of large stones form the nearby riverbank. Underside of the Pa'Dalih longhouse constructed in the late 1970s. 


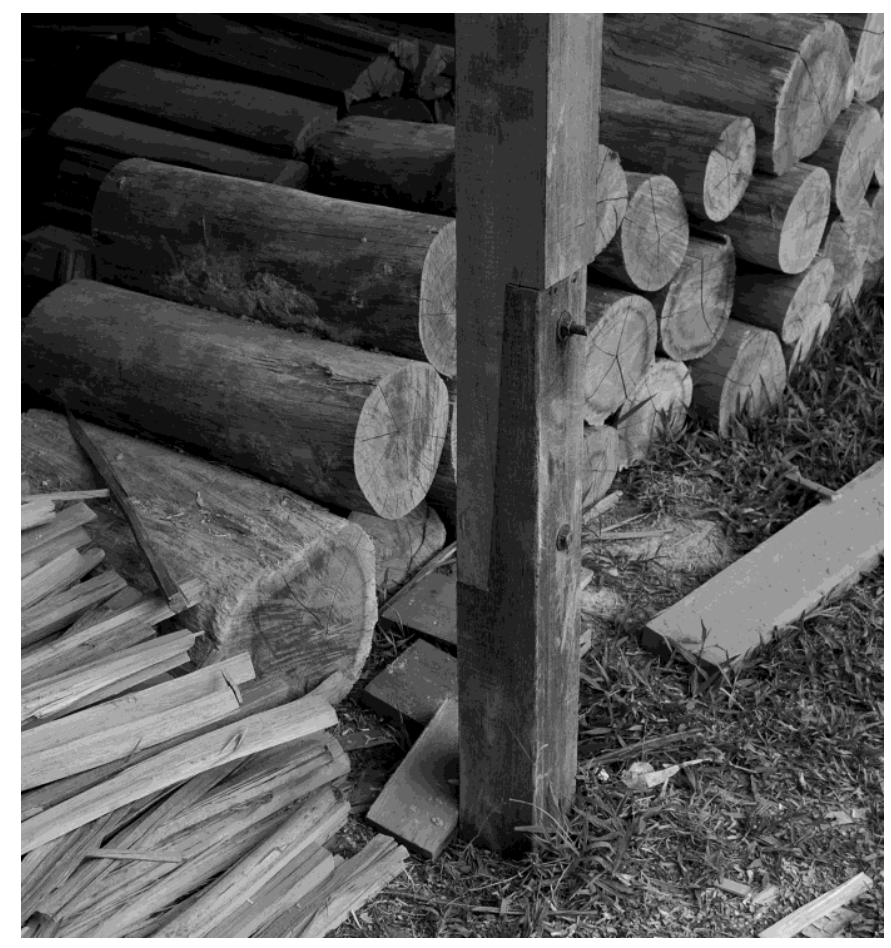

Figure 2b: Wooden foundation: belian (ironwood) bolted to local hardwood. 


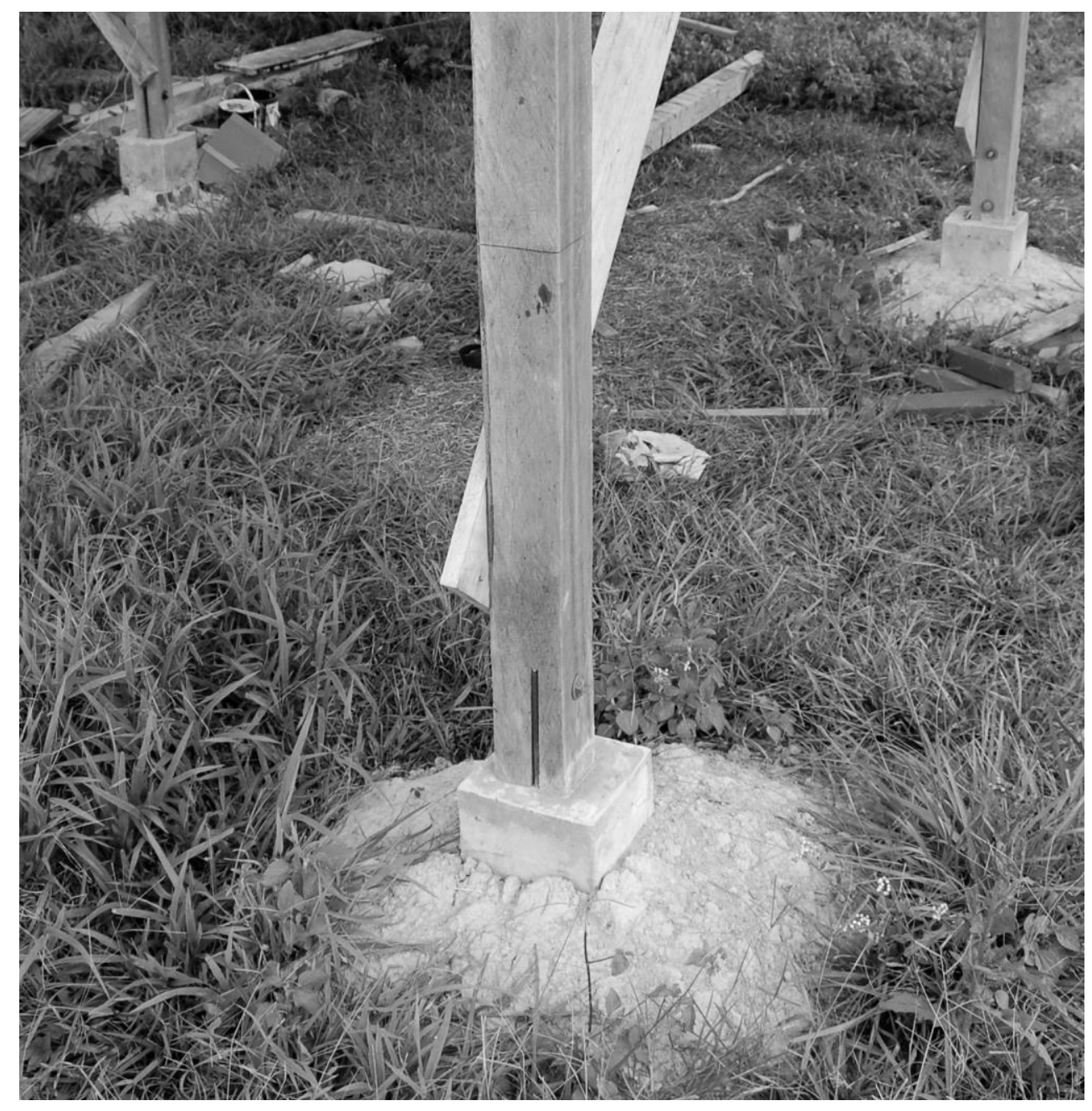

Figure 2c: Concrete footing with metal mounting plate. Close up of the foundations of the house in Figure 3. 


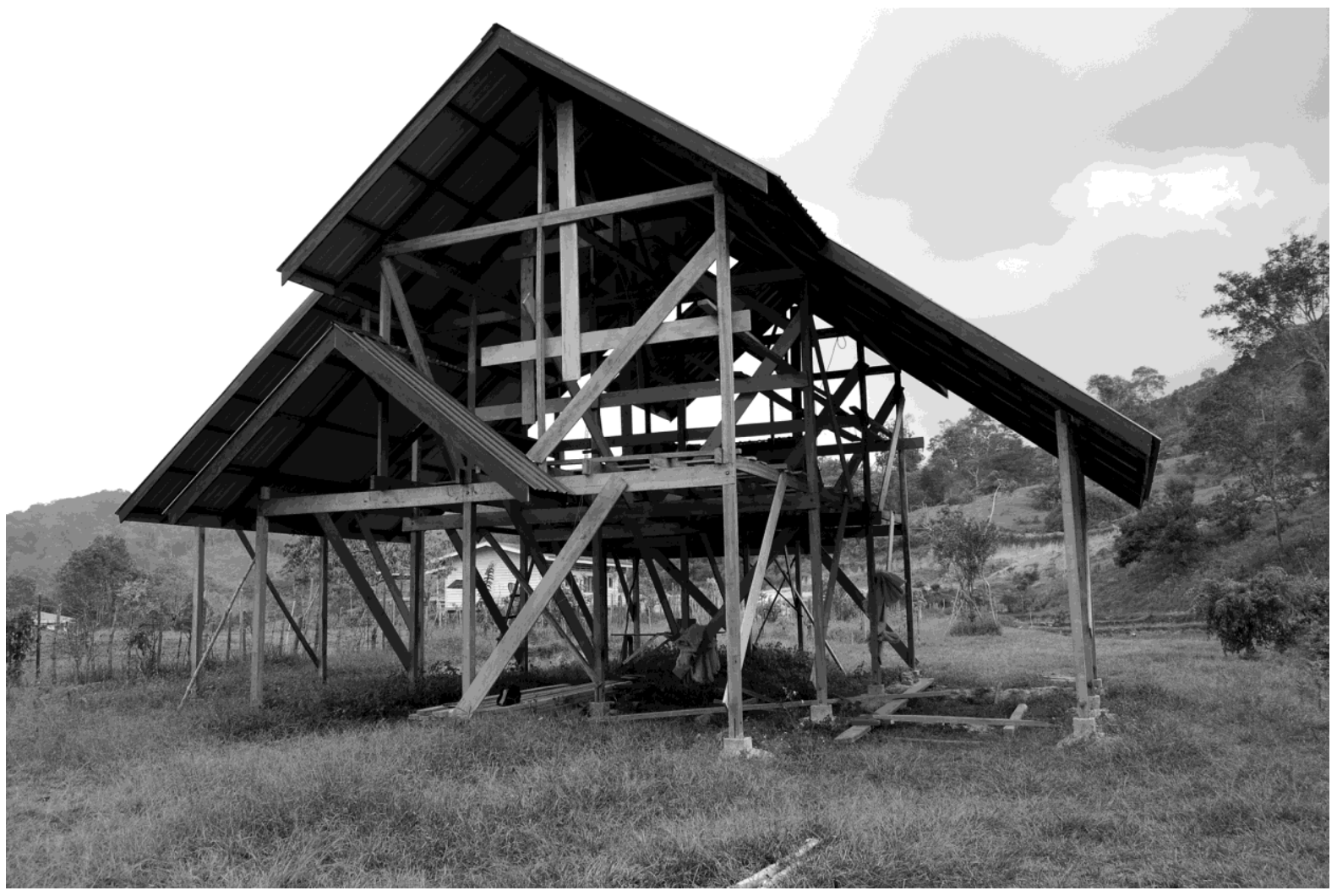

Figure 3: Modern housing: Individual house with 2 storeys; (green) painted aluminium roof with insulation under; metal and concrete foundations. 